\title{
Influence of soil contamination before and after ensiling on mineral composition of grass silages, feed intake and carry-over to body tissue of goats
}

\author{
S.D. Martens ${ }^{1,6}$, A. Majewska-Pinda ${ }^{1,2}$, A. Benkmann ${ }^{3,4}$, J. Zentek ${ }^{5}$, M. Spolders ${ }^{4}$, A. Simon ${ }^{3}$, \\ H. Schafft ${ }^{4}$ and O. Steinhöfel ${ }^{1}$ \\ ${ }^{1}$ Saxon State Office for Environment, Agriculture and Geology, Department of Animal Husbandry, 04886 Kölitsch, Germany \\ ${ }^{2}$ Wrockaw University of Environmental and Life Sciences, Department of Animal Nutrition and Feed Management \\ 51-631 Wrocław, Poland \\ ${ }^{3}$ Humboldt Universität zu Berlin, Faculty of Life Sciences, 10115 Berlin, Germany \\ ${ }^{4}$ Federal Institute for Risk Assessment (BfR), 10589 Berlin, Germany \\ ${ }^{5}$ Freie Universität Berlin, Department of Veterinary Medicine, Institute of Animal Nutrition, 14195 Berlin, Germany
}

KEY WORDS: tissues, goats, grass silage, iron, soil, trace elements

Received: 4 December 2017

Revised: 12 September 2018

Accepted: 11 December 2018

${ }^{6}$ Corresponding author:

e-mail: siriwan.martens@smul.sachsen.de

\begin{abstract}
Iron (Fe) is ubiquitous in the environment and has possible impact on quality and safety of feed and food due to the fact that it can be transferred from soil to animal feed and further to the products of animal origin. Therefore, the objective of the present study was to evaluate the effect of contamination of forage with soil differing in Fe concentration on Fe solubility, mineral composition and quality of grass silages. Furthermore, the effect of feeding these silages on feed intake, performance, trace element absorbability and carry-over into edible tissues was tested in young goats. Two ensiling experiments revealed that treating grass without or with different levels and types of soil before ensiling did not affect fermentation parameters of silages. Nevertheless, the addition of soil caused a highly significant increase of crude ash and trace elements contents in forage and silages. During ensiling, the in vitro solubility of $\mathrm{Fe}$ increased on average 5 times. Also, the aluminium content was the best indicator of soil contamination in forages. In a feeding trial with growing goats, feed intake and live weight gain were decreased in the group fed grass ensiled with the soil in contrast to the control group and animals receiving feed with soil added just before feeding. Fe concentration was highest in the duodenal tissue of kids fed the forage contaminated with soil before ensiling (184 vs 88-80 mg Fe/kg DM in the other two treatments), which might be also an indicator of Fe regulating properties. Fe concentration in the liver increased likewise. In conclusion, data indicate that ingesting ensiled soil impairs animal performance.
\end{abstract}

\section{Introduction}

Iron $(\mathrm{Fe})$ is a ubiquitous element. It is present also in the rumen of cattle, sheep and goats. Drinking water, feed naturally rich in Fe, phosphate supplements and forage products from grassland as well as from abrasion from agricultural machinery are relevant sources of Fe (Hansen and Spears, 2009). The recommendations of daily Fe supplementation in cattle and goats are rather similar and amount to $50 \mathrm{mg}$ and $40-50 \mathrm{mg}$ per $\mathrm{kg}$ dietary dry matter (DM), respectively (GfE, 2001, 2003; NRC, 2001; The European Union (EU) Regulation (EG) No. 1334/2003 (EU, 2003) allows a maximum Fe level 
of $750 \mathrm{mg} / \mathrm{kg}$ (at $88 \% \mathrm{DM}$ ) as a feed additive in complete feed, while the EFSA Panel on Additives and Products or Substances used in Animal Feed (FEEDAP) considered $450 \mathrm{mg} / \mathrm{kg} \mathrm{DM}$ as safe for bovines (EFSA, 2016). For sheep, a maximum tolerable level in the EU is $500 \mathrm{mg} / \mathrm{kg}$ feed DM (EFSA, 2016).

On the other hand, after a long-term monitoring (years 2000-2014) of cattle feed in Saxony it was revealed that a great part of analysed grass $(n=394)$ and lucerne $(\mathrm{n}=167)$ silages plus a small percentage of total mixed rations $(n=1733)$ exceeded the threshold of $450 \mathrm{mg} / \mathrm{kg}$ (Steinhöfel et al., 2016).

In general, $\mathrm{Fe}$ is present in soil mostly in an insoluble form characterized by a low absorbability. The non-ionic form of $\mathrm{Fe}$ passes the intestine without harming health and productivity of animals (Hansen and Spears, 2009). However, Healy (1972) demonstrated that in gastrointestinal fluids of ruminants $\mathrm{Fe}$ compounds from soil may be partly soluble. The released Fe ions can be absorbed or affect the mineral composition of the digesta. They may also have antagonistic effects - by binding with other elements they reduce their solubility and absorption. The solubility of $\mathrm{Fe}$ compounds is enhanced in an acidic environment (Hansen and Spears, 2009). An increased absorbability of $\mathrm{Fe}$ in forages contaminated with soil has been described and may be due to a reduction of ferric Fe to ferrous Fe during ensiling (Whitehead, 2000).

Animals are able to control their Fe metabolism strictly by homeostatic mechanisms. Free Fe is highly reactive and thus toxic, but on the other hand (pathogenic) bacteria can grow faster in $\mathrm{Fe}$ abundant environments (Ganz, 2003). Hepcidin has been identified as a key hormone stimulating Fe absorption especially in regular and suboptimal Fe supply conditions (Ganz, 2003; Enculescu et al., 2017). Furthermore, also hepcidin-independent mechanisms are discussed, especially during excess $\mathrm{Fe}$ supply, called dietary uptake saturation (Enculescu et al., 2017). However, despite the indicated mechanisms of Fe homeostasis, an excess Fe supply of cattle and sheep has been described to decrease feed intake and having antagonistic effects to other trace elements such as $\mathrm{Cu}, \mathrm{Zn}$ and $\mathrm{Mn}$. Furthermore, Fe excess causes poor appetite, decreased feed utilization and decreased body weight gain (Standish et al., 1969; Flachowsky et al., 1976; Grün et al., 1978; Lamand et al., 1979; Suttle, 2010).

Therefore, in this study it was hypothesized that the contamination of forage with mineral soil from different origins increases the $\mathrm{Fe}$ content and impairs fermentation quality of grass silages.
Furthermore, it was expected that ensiling increases Fe solubility and thus absorbability in the animal's gastrointestinal tract. Other analytical parameters than crude ash can better differentiate mineral content from forage vs soil. It was also tested if the time of forage contamination with soil (before and after ensiling) affects animal performance and accumulation of trace elements in tissues of goats.

\section{Material and methods}

\section{Quality and mineral composition of laboratory scale silages (Trial 1)}

Grass silages were prepared from forage harvested on July 1, 2014, from semi-intensive grassland in Northern Saxony (Germany), and wilted to 25 or $45 \%$ DM. Grass was chopped by an electric garden shredder (AXT 2200, Bosch, Stuttgart, Germany) to a theoretical length of $3 \mathrm{~cm}$. Mineral soil of varying Fe content (23 200 and $48700 \mathrm{mg} \mathrm{Fe} / \mathrm{kg} \mathrm{DM}, \mathrm{Fe}_{\text {Low }}$ and $\mathrm{Fe}_{\mathrm{High}}$, respectively) from two locations in Saxony was dried at $65^{\circ} \mathrm{C}$ and milled using a Pulverisette 14 (Fritsch, Idar-Oberstein, Germany) (2.0 mm sieve) to achieve high homogeneity. Each of the two wilting levels were treated as follows: no contamination with soil (Control), low contamination with soil $\left(\mathrm{Fe}_{\text {Low }}\right)$ and high contamination with soil $\left(\mathrm{Fe}_{\mathrm{High}}\right)$, both at $100 \mathrm{~g} / \mathrm{kg}$ forage DM, resulting in six treatments in total. Beside iron, the soils $\mathrm{Fe}_{\text {Low }}$ and $\mathrm{Fe}_{\text {High }}$ contained 56500 and $76500 \mathrm{mg} \mathrm{Al} / \mathrm{kg} \mathrm{DM}$, respectively, as well as 372000 and $316000 \mathrm{mg} \mathrm{Si} / \mathrm{kg} \mathrm{DM}$, respectively. The content of $\mathrm{Zn}, \mathrm{Mn}$ and $\mathrm{Cu}$ was slightly higher in soil $\mathrm{Fe}_{\text {High }}$ than in soil $\mathrm{Fe}_{\text {Low. }}$.

For ensiling at laboratory scale, 1.5-1 preserving jars with spring clips and rubber bands (Weck ${ }^{\circledR}$, Wehr, Germany) were used as experimental silos (three silos per treatment). The forage was thoroughly mixed with soil by hand. Each silo was tightly packed with $650 \mathrm{~g}$ forage fresh matter independent of wilting level. Control treatments without soil addition were also ensiled at both wilting levels. All treatments were left to ferment for 60 days. Thereafter, silos were opened and the $\mathrm{pH}$ was measured immediately and sensory evaluation was carried out according to the German Agricultural Society (Deutsche Landwirtschafts-Gesellschaft DLG) guideline (DLG, 2004). Subsamples underwent an aerobic stability test according to Honig (1990), in which temperature rise against ambient temperature was measured during 6.25 days of aerobic storage. The remaining amount of silages was stored at $-20{ }^{\circ} \mathrm{C}$ until further analysis. 
Chemical composition of forage and silages was determined at the Saxon State Company for Environment and Agriculture (BfUL) according to standard methods (VDLUFA, 1976). The content of the following components was analysed: DM, crude ash, crude protein, crude fibre, sugar (LuffSchoorl method), ADFom and aNDFom [acid detergent fibre (ADF) and neutral detergent fibre (NDF) expressed on organic matter basis] as well as ammonium. $\mathrm{HCl}$ insoluble ash was determined according to the Association of German Agricultural Analytic and Research Institutes (Verband Deutscher Landwirtschaftlicher Untersuchungsund Forschungsanstalten VDLUFA) (VDLUFA, 1997). Mineral composition was determined in soils, forages and silages by means of S8 Tiger apparatus (Bruker, Karlsruhe, Germany) with X-Ray fluorescence. The dietary cation-anion difference (DCAD) was calculated (Ender et al., 1971). Ensiling quality was evaluated chemically (DLG, 2006) based on $\mathrm{pH}$ values related to DM content and content of butyric acids (sum of C4:0-C6:0 acids: $\mathrm{n}$ butyric, isobutyric, n-valeric, isovaleric, n-caproic) and acetic acid (sum of $\mathrm{C} 2: 0-\mathrm{C} 3: 0$ acids: acetic, propionic) analysed with Reversed Phase-HPLC (LC-20A Prominence, Shimadzu Deutschland $\mathrm{GmbH}$, Duisburg, Germany; column Hi-Plex H $8 \mu \mathrm{m}, 300 \times 7.7 \mathrm{~mm}$, Agilent, Santa Clara, CA, USA).

Data obtained in the study were subjected to a two-way analysis of variance by STATISTICA version 10 (StatSoft PL, Kraków, Poland) and the significance of differences was estimated by Duncan's test at $\alpha=0.05$. The effects of DM and soil addition and their possible interactions were tested.

\section{Ensiling trial to test Fe solubility before and after ensiling (Trial 2)}

In a separate ensiling experiment, carried out in May 2010 in Middle Saxony (Germany), Italian ryegrass (Lolium multiflorum) was cut, wilted and chopped to $3 \mathrm{~cm}$ theoretical length by a forage harvester. A chemical silage additive containing hexamine and $\mathrm{NaNO}_{2}$ was applied at $2 \mathrm{ml}$ per $\mathrm{kg}$ fresh matter (FM). Mineral soil from ten different farm locations with $\mathrm{Fe}$ contents ranging from 1600 to $11300 \mathrm{mg} / \mathrm{kg} \mathrm{DM}$, prepared as described above, was added at 40 or $80 \mathrm{~g}$ per $\mathrm{kg}$ forage DM, respectively, and mixed thoroughly. The resulting 20 treatments were ensiled in triplicate in 2.5-1 Weck $^{\circledR}$ jars (around 1200-1400 g FM per jar) for 96 days. Fermentation quality was assessed by sensory eval- uation. Crude ash and $\mathrm{Fe}$ contents were determined before and after ensiling, the latter by atomic absorption spectroscopy at the Freie Universität Berlin (Germany). As indicator for bioaccessibility, Fe solubility before and after ensiling was assessed, following a method adapted from Hansen and Spears (2009). Briefly, different forage treatments before ensiling and silages were freeze dried and milled by a centrifugal mill (Retsch, Haan, Germany) to $0.5 \mathrm{~mm}$. The freeze dried material $(1 \mathrm{~g})$ was mixed with $40 \mathrm{ml}$ distilled water and extracted at a shaking rate of $80 / \mathrm{min}$ for $5 \mathrm{~h}$ in a laboratory shaker. The supernatant was then filtered through an ash free filter. The total content of $\mathrm{Fe}$ and the $\mathrm{Fe}$ content in the supernatant (soluble part) were analysed according to Annex IV, C (Commission of the European Communities, 2009).

The data were analysed by descriptive statistics. The effects of ensiling and the added soil level were tested by the Univariate procedure using SPSS $^{\circledR}$ Statistics version 19 (IBM ${ }^{\circledR}$, Armonk, NY, USA) applying a significance level of $\alpha=0.05$.

\section{Silage preparation for the feeding experiment}

Italian ryegrass was cut on a farm in the Ore Mountains (Germany) in July 2010. The grass was wilted (targeted at $300 \mathrm{~g} / \mathrm{kg}$, final DM about $405 \mathrm{~g} / \mathrm{kg}$ ). It was chopped to a nominal length of $40 \mathrm{~mm}$ and baled (John Deere 744 Premium Wrapping Baler (Deere \& Company, Arc-lès-Gray, France) with a MaxiCut 25-knife fine chop pre-cutter) to produce 8 wrapped bales of silage [used for control and Soil ${ }_{\text {post }}$ (contaminated after ensiling) groups] to give a total of $3.12 \mathrm{t} \mathrm{DM}$. For the Soil ${ }_{\text {pre }}$ treatment (contaminated before ensiling), $14 \mathrm{~g}$ fresh topsoil from the farm's cropland was applied by hand per $\mathrm{kg}$ wilted forage FM on the swath. The soil contained $717 \mathrm{~g}$ crude ash, $8300 \mathrm{mg} \mathrm{Fe}, 11 \mathrm{mg} \mathrm{Zn}$, $134 \mathrm{mg} \mathrm{Mn}$ and $6 \mathrm{mg} \mathrm{Cu}$ per $\mathrm{kg} \mathrm{DM}$. The swath was taken up, chopped, baled and wrapped in four bales accordingly to give a total of $1.25 \mathrm{t} \mathrm{DM}$.

The Soil post $_{\text {treatment was prepared using dried }}$ soil from the same site as for Soil pre $_{\text {, }}$ aiming at a similar final Fe content of the diet.

\section{Feeding experiment}

The trial comprised three feeding groups of eight growing animals each (male goats, German goat breed 'Weisse Deutsche Edelziege'). Due to the time needed to get the approval from the Ethical commission (Reg 0331/10, Landesamt für 
Gesundheit und Soziales Berlin) it was carried out only in 2012. At the start of the experiment, the animals were 6 weeks old and had an average live weight of $11.8 \pm 2.8 \mathrm{~kg}$. Two animals per unit were kept together to assess the feed intake. The period to adapt to grass silage as sole feed component lasted 14 days. The trial was conducted on the experimental station of the Federal Institute for Risk Assessment (BfR) in Berlin (Germany) and lasted 85 days. The animals were assigned to three treatments: control (grass silage without soil contamination), Soil $1_{\text {pre }}$ (grass silage contaminated with soil before ensiling) and Soil ${ }_{\text {post }}$ (grass silage contaminated with soil at $130 \mathrm{~g} / \mathrm{kg} \mathrm{DM}$ after ensiling just before feeding).

The goats were fed the respective grass silages once a day ad libitum, i.e. depending on their foregoing intake they were fed around 200 $300 \mathrm{~g}$ DM on day 8 which was increased to 480 $740 \mathrm{~g}$ DM on day 85 of the experiment. To achieve a live weight gain of $50 \mathrm{~g} /$ day a male kid of $15 \mathrm{~kg}$ needs around 4.5 MJ ME/day, and 5.7 MJ ME with $20 \mathrm{~kg}$ live weight which corresponds to about 410 and $520 \mathrm{~g} \mathrm{DM}$ at $11 \mathrm{MJ} \mathrm{ME} / \mathrm{kg} \mathrm{DM}$ (GfE et al., 2003). During the experiment, animals were weighed weekly to calculate the daily weight gain. Feed left-overs were recorded daily. Feed samples were taken daily, frozen and pooled for analysis of crude ash and trace elements. All 24 goats from the experiment were slaughtered after experimental feeding. At slaughtering, samples were taken from the back muscle (Musculus longissimus dorsi), from the ham (Musculus glutaeus maximus), the liver, the kidneys and the duodenal tissue. Animal tissue and feed samples were analysed for $\mathrm{Fe}, \mathrm{Zn}, \mathrm{Cu}$ and $\mathrm{Mn}$ by atomic absorption spectroscopy (contra ${ }^{\circledR}$ AA 700, Analytik Jena AG, Jena, Germany) in the laboratory of the Institute for Animal Nutrition, Department of Veterinary Medicine, Freie Universität Berlin (Germany). The samples were prepared by freeze drying, milling and incineration. The crude ash was treated with concentrated $\mathrm{HCl}$ and distilled water before heating in a sand bath and filtering through a folded filter.

Data obtained in the feeding trial were subjected to the procedure Univariate by SPSS $^{\circledR}$ Statistics ver. $19\left(\mathrm{IBM}^{\circledR}\right.$, Armonk, NY, USA) evaluating the treatment effect (for the analysis of the tissue also the effect of the type of tissue and a possible interaction between type of tissue and treatment) and Tukey-HSD post hoc test at a significance level of $\alpha=0.05$.

\section{Results}

\section{Quality and mineral composition of laboratory scale silages (Trial 1)}

The chemical composition of silages contaminated with soil or not is presented in Table 1 . The content of crude ash was high $(>100 \mathrm{~g} / \mathrm{kg} \mathrm{DM})$ in all silages and exceeded $170 \mathrm{~g} / \mathrm{kg}$ DM when treated with soil $(P<0.001)$. Contents of manganese and all other analysed trace elements in silages were significantly $(P<0.01)$ higher at $25 \%$ DM compared to $45 \%$ DM. In soil contaminated silages, the increase of acid insoluble ash was even more pronounced and reached about the 2.5 fold over the control. The soil contamination caused a reduction of crude protein content by about 5 to $20 \mathrm{~g} / \mathrm{kg} \mathrm{DM}(P<0.05)$ and of the fibre fractions (ADFom and aNDFom) by about $25 \mathrm{~g} / \mathrm{kg}(P<0.05)$. Macro-elements like sodium, chloride and potassium were not distinctively affected by treatments, only the sulphur content was decreased $(P<0.05)$ and the $\mathrm{Mg}$ content was increased $(P<0.001)$. These changes did not affect the Dietary Cation-Anion Difference (DCAD) of silages, which was similar between the treatments (Table 1). As expected, the addition of soil caused a highly significant $(P<0.001)$ increase of $\mathrm{Fe}$ (up to 34 fold), but also of manganese (4 fold), silicon ( 2 fold) and aluminium (80-100 fold) contents, especially in $\mathrm{Fe}_{\mathrm{High}}$ treatment. There were no consistent differences in mineral concentration in the experimental silages in comparison to the corresponding initial materials (data not shown). In general, the ensiling quality of all the silages was good (Table 1) and only the DM level affected the $\mathrm{pH}$ value. The contamination with soil did not change the measured parameters significantly. Despite some differences in butyric acid contents among DM levels, there was no indication of strong butyric acid fermentation (butyric acid $<10 \mathrm{~g} / \mathrm{kg} \mathrm{DM}$ ).

The ammonia nitrogen concentration as indicator for deamination was similar in all silages and slightly above the critical value of $80 \mathrm{~g} / \mathrm{kg} \mathrm{N}$. All silages were aerobically stable for $>4$ days, surpassing the critical first 3 days.

\section{Ensiling trial to test Fe solubility before and after ensiling (Trial 2) (Trial 2)}

The addition of two levels of soil from 10 different origins resulted in Fe levels ranging from 531 to $3-714 \mathrm{mg} / \mathrm{kg}$ DM with significant differences caused by soil level (Table 2). Before ensiling, about $7 \%$ of the Fe was soluble 
Table 1. Chemical composition of silages, g/kg dry matter (DM) (if not stated differently) (Trial 1)

\begin{tabular}{|c|c|c|c|c|c|c|c|c|c|}
\hline \multirow{2}{*}{ Indices } & \multicolumn{2}{|c|}{ DM in forage, $\%$} & \multicolumn{3}{|c|}{ Treatments $^{1}$} & \multicolumn{3}{|l|}{$P$-value } & \multirow{2}{*}{ SEM } \\
\hline & 25 & 45 & Control & $\mathrm{Fe}_{\text {Low }}$ & $\mathrm{Fe}_{\text {High }}$ & $\mathrm{DM}$ & Soil & DM $\times$ Soil & \\
\hline \multicolumn{10}{|l|}{ Nutrients } \\
\hline $\mathrm{DM}, \mathrm{g} / \mathrm{kg}$ & $266.5^{\mathrm{B}}$ & $481.7^{\mathrm{A}}$ & 358.7 & 376.3 & 400.8 & $<0.001$ & 0.621 & 1.000 & 27.2 \\
\hline Crude ash & $159.8^{A}$ & $148.5^{\mathrm{B}}$ & $114.3^{\mathrm{B}}$ & $171.7^{\mathrm{A}}$ & $172.5^{\mathrm{A}}$ & 0.001 & $<0.001$ & 0.244 & 6.7 \\
\hline Acid insoluble ash & $74.3^{\mathrm{A}}$ & $66.9^{\mathrm{B}}$ & $33.9^{\mathrm{B}}$ & $90.3^{A}$ & $84.6^{A}$ & 0.001 & $<0.001$ & 0.123 & 6.1 \\
\hline Crude protein* & $161.5^{\mathrm{B}}$ & $177.3^{\mathrm{A}}$ & $186.0^{\mathrm{Aa}}$ & $171.2^{b}$ & $165.7^{\mathrm{B}}$ & 0.009 & 0.022 & 0.840 & 3.5 \\
\hline Crude fibre* & 237.4 & 230.8 & $250.48^{A}$ & $222.6^{\mathrm{B}}$ & $225.6^{\mathrm{B}}$ & 0.249 & 0.005 & 0.031 & 4.2 \\
\hline ADFom* ${ }^{*}$ & 249.5 & 245.0 & $264.5^{\mathrm{A}}$ & $236.0^{B}$ & $236.7^{\mathrm{B}}$ & 0.536 & 0.006 & 0.888 & 4.5 \\
\hline aNDFom* & 471.0 & 479.3 & $506.4^{\mathrm{A}}$ & $465.1^{\mathrm{B}}$ & $462.3^{\mathrm{B}}$ & 0.536 & 0.023 & 0.734 & 7.5 \\
\hline \multicolumn{10}{|l|}{ Minerals } \\
\hline DCAD, meq/kg DM & 308 & 324 & 316 & 312 & 320 & 0.300 & 0.933 & 0.926 & 6.5 \\
\hline $\mathrm{Na}$ & $0.4^{\mathrm{a}}$ & $0.3^{b}$ & $0.31^{b}$ & $0.44^{a}$ & $0.37^{\mathrm{ab}}$ & 0.048 & 0.034 & 0.998 & 0.0 \\
\hline $\mathrm{K}$ & 30.0 & 29.6 & 30.6 & 29.4 & 29.5 & 0.408 & 0.053 & 0.734 & 0.2 \\
\hline$S$ & 3.4 & 3.3 & $3.5^{\mathrm{a}}$ & $3.3^{b}$ & $3.3^{b}$ & 0.463 & 0.016 & 0.657 & 0.0 \\
\hline C & 9.5 & 8.6 & 9.4 & 9.1 & 8.7 & 0.179 & 0.734 & 0.965 & 0.3 \\
\hline $\mathrm{Ca}$ & $6.9^{\mathrm{a}}$ & $6.4^{\mathrm{b}}$ & 6.8 & 6.6 & 6.6 & 0.020 & 0.621 & 0.589 & 0.1 \\
\hline$P$ & $3.6^{\mathrm{A}}$ & $3.3^{\mathrm{B}}$ & 3.5 & 3.4 & 3.4 & 0.001 & 0.640 & 0.904 & 0.0 \\
\hline $\mathrm{Mg}$ & $1.9^{\mathrm{A}}$ & $1.8^{\mathrm{B}}$ & $1.7^{\mathrm{C}}$ & $1.8^{\mathrm{B}}$ & $2.0^{\mathrm{A}}$ & $<0.001$ & $<0.001$ & 0.018 & 0.0 \\
\hline $\mathrm{Fe}, \mathrm{mg} / \mathrm{kg} \mathrm{DM}$ & $2099^{A}$ & $1707^{\mathrm{B}}$ & $235^{\mathrm{C}}$ & $1813^{\mathrm{B}}$ & $3381^{\mathrm{A}}$ & $<0.001$ & $<0.001$ & $<0.001$ & 321 \\
\hline $\mathrm{Mn}, \mathrm{mg} / \mathrm{kg} \mathrm{DM}$ & $84^{\mathrm{A}}$ & $74^{\mathrm{B}}$ & $34^{c}$ & $92^{\mathrm{B}}$ & $106^{\mathrm{A}}$ & 0.001 & $<0.001$ & 0.067 & 8 \\
\hline $\mathrm{Zn}, \mathrm{mg} / \mathrm{kg} \mathrm{DM}$ & $45^{\mathrm{A}}$ & $42^{\mathrm{B}}$ & $40^{B}$ & $41^{\mathrm{B}}$ & $49^{A}$ & 0.005 & $<0.001$ & 0.076 & 1 \\
\hline $\mathrm{Cu}, \mathrm{mg} / \mathrm{kg} \mathrm{DM}$ & $9.5^{\mathrm{A}}$ & $8.8^{\mathrm{B}}$ & $8.2^{\mathrm{B}}$ & $8.4^{\mathrm{B}}$ & $10.5^{\mathrm{A}}$ & 0.001 & $<0.001$ & 0.011 & 0 \\
\hline $\mathrm{Si}, \mathrm{g} / \mathrm{kg}$ & $34.6^{\mathrm{A}}$ & $31.7^{\mathrm{B}}$ & $25.5^{\mathrm{B}}$ & $37.2^{\mathrm{A}}$ & $36.0^{\mathrm{A}}$ & 0.003 & $<0.001$ & 0.287 & 1.3 \\
\hline $\mathrm{Al}, \mathrm{mg} / \mathrm{kg} \mathrm{DM}$ & $2802^{A}$ & $2198^{B}$ & $60^{c}$ & $2764^{\mathrm{B}}$ & $4322^{A}$ & $<0.001$ & $<0.001$ & 0.002 & 439 \\
\hline \multicolumn{10}{|l|}{ Fermentation parameters } \\
\hline Storage losses, \% FM & 1.0 & 1.0 & 1.1 & 1.0 & 0.9 & 0.660 & 0.485 & 0.703 & 0.1 \\
\hline Aerobic stability, $\mathrm{h}$ & 131 & 141 & 100 & 143 & 150 & 0.515 & 0.110 & 0.317 & 9 \\
\hline $\mathrm{NH}_{3}-\mathrm{N}, \%$ total $\mathrm{N}$ & 9.6 & 9.2 & 9.8 & 9.3 & 9.2 & 0.498 & 0.714 & 0.920 & 0.3 \\
\hline $\mathrm{pH}$ & $4.06^{\mathrm{B}}$ & $4.72^{\mathrm{A}}$ & 4.50 & 4.36 & 4.37 & $<0.001$ & 0.243 & 0.931 & 0.1 \\
\hline Butyric acid & $0.00^{B}$ & $0.91^{\mathrm{A}}$ & 0.5 & 0.5 & 0.5 & 0.007 & 0.958 & 0.958 & 0.2 \\
\hline Acetic acid & 7.3 & 7.5 & 8.1 & 6.9 & 7.3 & 0.644 & 0.113 & 0.001 & 0.3 \\
\hline Ethanol & 0.7 & 0.7 & 0.8 & 0.6 & 0.6 & 0.882 & 0.146 & 0.781 & 0.0 \\
\hline DLG sensory quality ${ }^{2}$ & 2.0 & 3.9 & 1.8 & 3.8 & 3.2 & 0.156 & 0.406 & 0.349 & 0.6 \\
\hline Ensiling quality ${ }^{3}$ & $95.6^{\mathrm{B}}$ & $98.5^{\mathrm{A}}$ & $95.0^{\mathrm{B}}$ & $97.5^{\mathrm{A}}$ & $98.6^{\mathrm{A}}$ & $<0.001$ & $<0.001$ & 0.006 & 0.6 \\
\hline
\end{tabular}

ADFom - acid detergent fibre expressed exclusive of residual ash, aNDFom - neutral detergent fibre assayed with a heat stable amylase and expressed exclusive of residual ash, DCAD dietary cation-anion difference; ${ }^{1}$ treatments: Control - forage crop without soil contamination, $\mathrm{Fe}_{\mathrm{L}}$ - forage contamination with soil of low Fe content, $\mathrm{Fe}_{\text {ioh }}$ - forage contamination with soil of high Fe content; ${ }^{2} \mathrm{DLG}$ sensory quality: marks from 1 to 5 (very good to very poor); ${ }^{3}$ ensiling quality points based on chemical analysis: up to 100 (best quality); ${ }^{*}$ determined from forage before ensiling; ${ }^{\text {ab }}$ - means within the same row and treatment not sharing the same superscript are significantly different at $P<0.05$; ${ }^{A B C}-$ means within the same row and treatment not sharing the same superscript are significantly different at $P<0.01$

Table 2. Contents of crude ash and Fe (means of fresh and ensiled forage) and Fe solubility before (fresh) and after ensiling (Trial 2)

\begin{tabular}{|c|c|c|c|c|c|c|c|c|c|c|}
\hline & \multicolumn{6}{|c|}{ Added soil per kg forage dry matter (DM) } & \multirow{3}{*}{$\begin{array}{l}\text { Overall } \\
\text { mean }\end{array}$} & \multirow{3}{*}{ SD } & \multicolumn{2}{|l|}{$P$-value } \\
\hline & \multicolumn{3}{|l|}{$+40 \mathrm{~g}$} & \multicolumn{3}{|l|}{$+80 \mathrm{~g}$} & & & \multirow{2}{*}{ ensiling } & \multirow{2}{*}{$\begin{array}{l}\text { soil } \\
\text { level }\end{array}$} \\
\hline & mean & $\min$ & $\max$ & mean & $\min$ & $\max$ & & & & \\
\hline Crude ash, g/kg DM & 126 & 119 & 134 & 148 & 137 & 166 & 136 & 14.8 & 0.818 & $<0.001$ \\
\hline $\mathrm{Fe}, \mathrm{mg} / \mathrm{kg} \mathrm{DM}$ & 898 & 531 & 1541 & 1606 & 812 & 3714 & 1254 & 733.0 & 0.225 & $<0.001$ \\
\hline \multicolumn{11}{|l|}{ Fe solubility, \% } \\
\hline Fresh & 7.00 & 4.76 & 11.09 & 6.61 & 4.04 & 13.19 & 6.81 & 2.273 & - & 0.718 \\
\hline Ensiled & 36.32 & 20.30 & 45.90 & 32.39 & 15.80 & 46.23 & 34.42 & 7.177 & $<0.001$ & 0.036 \\
\hline
\end{tabular}

SD - standard deviation 
in water. After ensiling, the Fe solubility raised to $19-42 \%$, which means on average a 4 -fold increase $(P<0.001)$.

\section{Feeding experiment}

In the silages contaminated with soil, the Fe concentration was 5- to 6-fold higher than in the control silage and more than two times higher than acceptable daily allowance for bovine and ovine (Table 3). The Fe content in the feed was numerically the highest in the Soil ${ }_{\text {post }}$ treatment, where soil was added after ensiling just before feeding (Table 3 ).

During the feeding trial, animals from Soil ${ }_{\text {post }}$ group showed the highest daily Fe intake (Table 4) as a consequence of higher feed intake. The daily feed intake was the lowest in Soil ${ }_{\text {pre }}$ group and the highest in Soil ${ }_{\text {post }}$ group, however the control group did not differ from neither Soil ${ }_{\text {pre }}$ or Soil ${ }_{\text {post }}$

Table 3. Nutrient composition and contents of $\mathrm{Fe}, \mathrm{Cu}, \mathrm{Zn}, \mathrm{Mn}$ of baled grass silages (or forages at ensiling*) (Feeding trial)

\begin{tabular}{|c|c|c|c|}
\hline \multirow[b]{2}{*}{ Indices } & \multicolumn{3}{|l|}{ Treatment $^{1}$} \\
\hline & $\begin{array}{l}\text { Control } \\
\text { (no contamination) }\end{array}$ & Soil $_{\text {pre }}$ & Soil $_{\text {post }}$ \\
\hline $\mathrm{DM}, \mathrm{g} / \mathrm{kg}$ & 298 & 317 & 336 \\
\hline \multicolumn{4}{|l|}{ Nutrients, g/kg DM } \\
\hline Crude ash & 120 & 157 & 173 \\
\hline Crude protein & 193 & 193 & \\
\hline Crude fibre & 280 & 249 & \\
\hline Ether extract & 51 & 51 & \\
\hline Sugar* & 149 & 136 & \\
\hline ADFom ${ }^{*}$ & 232 & 238 & \\
\hline $\mathrm{Ca}^{*}$ & 4.79 & 4.77 & \\
\hline$P^{*}$ & 3.41 & 3.50 & \\
\hline $\mathrm{Na}^{*}$ & 0.20 & 0.23 & \\
\hline $\mathrm{Mg}^{*}$ & 2.13 & 2.23 & \\
\hline$S^{*}$ & 2.45 & 2.44 & \\
\hline $\mathrm{Cl}^{*}$ & 3.51 & 3.29 & \\
\hline $\mathrm{Si}^{*}$ & n.a. & 11.30 & \\
\hline \multicolumn{4}{|l|}{$\mathrm{mg} / \mathrm{kg} \mathrm{DM}$} \\
\hline $\mathrm{Al}^{*}$ & n.a. & 1650 & \\
\hline $\mathrm{Fe}$ & 350 & 1713 & 2064 \\
\hline $\mathrm{Zn}$ & 27 & 30 & 42 \\
\hline $\mathrm{Mn}$ & 26 & 58 & 69 \\
\hline $\mathrm{Cu}$ & 8 & 8 & 9 \\
\hline NEL, MJ/kg DM* & 6.9 & 6.7 & \\
\hline $\mathrm{ME}, \mathrm{MJ} / \mathrm{kg} \mathrm{DM}^{*}$ & 11.2 & 11.0 & \\
\hline
\end{tabular}

1 Treatments: Control - without soil contamination, Soil pre - soil contamination before ensiling, Soil ${ }_{\text {post }}$ - soil contamination pre just before feeding; n.a. - not analysed; NEL - net energy for lactation; ME - metabolizable energy (GfE, 1995)
The daily live weight gain (LWG) of Soil ${ }_{\text {pre }}$ group was the lowest and was about half of the other two experimental groups (Table 4). Between treatments the weekly live weight development was clearly distinguished at the end of the feeding period at day 86 with the lowest live weight in Soil ${ }_{\text {pre }}$ group $(P=0.048$, Figure 1). Correspondingly, the feed conversion ratio was most limited in Soil ${ }_{\text {pre }}$ group (Table 4).

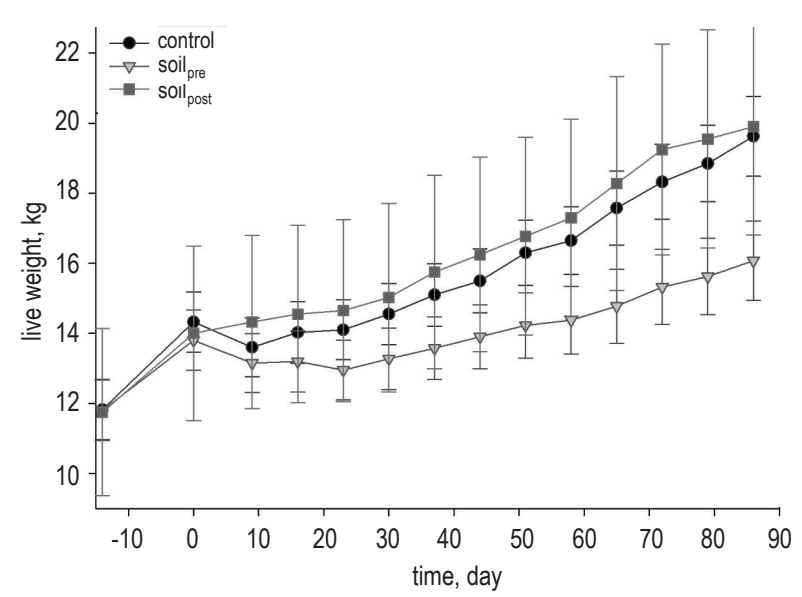

Figure 1. Live weight development of animals fed one of the treatments: control - without soil contamination, Soil ${ }_{\text {pre }}$ - soil contamination before ensiling, Soil ${ }_{\text {post }}$ - soil contamination after ensiling, just before feeding (means, error bars indicate standard error of the mean, $n=8$ )

Table 4. Dry matter intake (DMI) and Fe intake per animal per day and growth performance from experimental days 8 to 85 , feeding trial (means \pm standard deviation)

\begin{tabular}{|c|c|c|c|}
\hline \multirow[b]{2}{*}{ Indices } & \multicolumn{3}{|c|}{ Treatment $^{1}$} \\
\hline & $\begin{array}{l}\text { Control } \\
(n=4)\end{array}$ & $\begin{array}{l}\text { Soil } \\
(n=4) \\
(n=4)\end{array}$ & $\begin{array}{l}\text { Soil }_{\text {post }} \\
(n=4)\end{array}$ \\
\hline
\end{tabular}

Daily DMI, g/animal $387^{\mathrm{ab}} \pm 52.3 \quad 312^{\mathrm{b}} \pm 43.8 \quad 438^{\mathrm{a}} \pm 30.9 \quad 0.006$

Daily Fe intake, $\quad 135^{\circ} \pm 18.2 \quad 534^{\mathrm{b}} \pm 75.1874^{\mathrm{a}} \pm 95.5<0.001$ g/animal

$\mathrm{LW}, \mathrm{kg}(\mathrm{n}=8)$

$\begin{array}{ccccc}\text { day } 0 & 14.3 \pm 2.3 & 13.8 \pm 2.5 & 14.0 \pm 2.5 & 0.91 \\ \text { day } 85 & 19.6 \pm 3.5 & 16.1 \pm 3.0 & 19.9 \pm 3.1 & 0.048 \\ \text { Daily LWG, g/animal } & 78^{\mathrm{a}} & 38^{\mathrm{b}} & 72^{\mathrm{a}} & 0.002 \\ \begin{array}{l}\text { Feed conversion, } \\ \text { Fg DMI/kg LWG }\end{array} & 5.0^{\mathrm{b}} & 9.0^{\mathrm{a}} & 5.9^{\mathrm{b}} & 0.012\end{array}$
$\mathrm{kg} \mathrm{DMl/kg} \mathrm{LWG}$

${ }_{1}^{1}$ Treatments: Control - without soil contamination, Soil ${ }_{\text {pre }}$ - soil contamination before ensiling, Soil ${ }_{\text {post }}$ - soil contamination after ensiling, just before feeding; DMI dry matter intake; LW - live weight; LWG - live weight gain; ${ }^{a b c}$ - values with different superscripts within a row are significantly different at $P<0.05$ (Tukey-HSD)

by the kidneys and the duodenal tissue where significant differences between treatments were observed (Table 5). However, despite the low level, the Fe content in tissues of Soil pre group was significantly higher than for the other two treatments even in the 
ham. Only the Musculus longissimus dorsi showed no response to treatment in none of the analysed parameters. Copper also accumulated mostly in the liver (10-fold more in comparison to muscle meat), however it was not influenced by the treatments (Table 5). The zinc content was the highest in ham and liver. Elevated values in these tissues and in the intestinal wall were noted in Soil ${ }_{\text {pre }}$ group. The liver was also a main deposit for manganese, the muscle tissues contained only one tenth of this concentration (Table 5).

Table 5. Contents of dry matter (DM), crude ash and trace elements in tissues of goats after $86 \mathrm{~d}$ of experimental feeding (Feeding trial; $n=8$ )

\begin{tabular}{|c|c|c|c|c|c|c|}
\hline \multirow{2}{*}{ Indices } & \multirow{2}{*}{$\begin{array}{l}\mathrm{DM}, \\
\mathrm{g} / \mathrm{kg}\end{array}$} & \multirow{2}{*}{$\begin{array}{l}\text { Crude } \\
\text { ash, } \\
\text { g/kg DM }\end{array}$} & \multicolumn{3}{|c|}{ Trace elements, mg/kg DM } & \multirow[b]{2}{*}{$\mathrm{Mn}$} \\
\hline & & & $\mathrm{Fe}$ & $\mathrm{Zn}$ & $\mathrm{Cu}$ & \\
\hline \multicolumn{7}{|c|}{ Musculus longissimus dorsi } \\
\hline Control $^{1}$ & 207.7 & 44.2 & 40 & 80 & 4 & 0.3 \\
\hline Soil ${ }_{\text {pre }}^{1}$ & 206.4 & 46.0 & 36 & 78 & 3 & 0.3 \\
\hline Soil ${ }_{\text {post }}^{\text {pie }} 1$ & 209.5 & 42.0 & 39 & 71 & 3 & 0.2 \\
\hline SEM & 1.92 & 0.77 & 2.0 & 2.2 & 0.2 & 0.02 \\
\hline$P$-value & 0.809 & 0.131 & 10.671 & 0.248 & 0.208 & 0.187 \\
\hline \multicolumn{7}{|c|}{ Musculus glutaeus maximus } \\
\hline Control & 150.4 & 52.2 & $39^{b}$ & $108^{b}$ & 2.6 & $0.2^{\mathrm{a}}$ \\
\hline Soil $_{\text {pre }}$ & 148.8 & 51.3 & $57^{a}$ & $148^{a}$ & 4.5 & $0.4^{b}$ \\
\hline Soil $_{\text {post }}^{\text {pit }}$ & 147.3 & 51.4 & $44^{\mathrm{b}}$ & $133^{\mathrm{ab}}$ & 3.1 & $0.3^{\mathrm{ab}}$ \\
\hline SEM & 1.03 & 0.45 & 1.9 & 6.0 & 0.4 & 0.02 \\
\hline$P$-value & 0.490 & 0.692 & 20.005 & 0.044 & 0.099 & 0.031 \\
\hline \multicolumn{7}{|l|}{ Liver } \\
\hline Control & 207.7 & 49.7 & $298^{b}$ & 93 & 23 & 4.3 \\
\hline Soil $_{\text {pre }}$ & 213.9 & 49.8 & $574^{a}$ & 151 & 77 & 4.0 \\
\hline Soil $_{\text {post }}^{\text {pit }}$ & 210.1 & 49.1 & $426^{a b}$ & 95 & 22 & 4.6 \\
\hline SEM & 3.59 & 0.50 & 28.8 & 23.9 & 11.3 & 0.12 \\
\hline$P$-value & 0.768 & 0.866 & $6 \quad 0.003$ & 0.529 & 0.102 & 0.139 \\
\hline \multicolumn{7}{|l|}{ Kidneys } \\
\hline Control & 183.4 & 64.9 & $193^{b}$ & 70 & 14 & 1.7 \\
\hline Soil $_{\text {pre }}$ & 184.2 & 63.4 & $290^{\mathrm{a}}$ & 70 & 14 & 1.5 \\
\hline Soil $_{\text {post }}$ & 185.3 & 63.0 & $203^{b}$ & 71 & 14 & 1.8 \\
\hline SEM & 1.45 & 0.82 & 7.11 & 1.0 & 0.3 & 0.04 \\
\hline$P$-value & 0.864 & 0.612 & $2<0.001$ & 0.787 & 0.877 & 0.064 \\
\hline \multicolumn{7}{|c|}{ Duodenal tissue } \\
\hline Control & $208.7^{b}$ & 62.7 & $88^{b}$ & $57^{\mathrm{b}}$ & 3.3 & 1.34 \\
\hline Soil $_{\text {pre }}$ & $175.7^{\mathrm{a}}$ & 68.9 & $184^{\mathrm{a}}$ & $69^{a}$ & 4.1 & 2.71 \\
\hline Soil $_{\text {post }}$ & $211.5^{b}$ & 54.7 & $80^{b}$ & $53^{b}$ & 3.3 & 1.38 \\
\hline SEM & 5.41 & 2.53 & 8.6 & 1.8 & 0.2 & 0.27 \\
\hline$P$-value & 0.023 & 0.102 & $<0.001$ & 0.004 & 0.225 & 0.076 \\
\hline \multicolumn{7}{|c|}{$P$-value (overall) } \\
\hline Body tissue & $e<0.001$ & $<0.001$ & $<0.001$ & $<0.001$ & $<0.001$ & $<0.001$ \\
\hline Treatment & 0.092 & 0.021 & $<0.001$ & 0.146 & 0.060 & 0.343 \\
\hline $\begin{array}{l}\text { Body tissue } \\
x \text { treatment }\end{array}$ & 0.004 & 0.068 & $<0.001$ & 0.735 & 0.013 & 0.002 \\
\hline
\end{tabular}

${ }_{1}^{1}$ Treatments: Control - without soil contamination, Soil pre - soil contamination before ensiling, Soil ${ }_{\text {post }}$ - soil contamination after ensiling, just before feeding; SEM - standard error of the mean; ${ }^{\text {ab }}$ - the values with different superscripts within each column (for each tissue separately) are significantly different at $P<0.05$

\section{Discussion}

\section{Analytic indicators of soil contamination}

In feedstuffs, the crude ash content is a sum parameter for minerals. In grass silages, a content of $>100 \mathrm{~g} / \mathrm{kg}$ DM is usually undesired as it is commonly assumed to originate from soil contamination, which can dilute nutrients like crude protein and displace fibre components in the roughage. However, the presence of crude ash per se does not permit to clearly indicate the origin of minerals. Some pastures, especially when rich in herbs, can contain substantial amounts of plants' own minerals such as calcium. Thus, acid insoluble ash is recognized as parameter for the sand proportion (VDLUFA, 1997). The inclusion of $100 \mathrm{~g}$ soil/kg forage DM increased more than two times the concentration of acid insoluble ash (Table 1). The analysis of soil composition revealed that silicon and aluminium are the most and the second most abundant elements in mineral soils, respectively. However, the most pronounced difference of all analysed parameters in the silages without and with soil contamination can be found in the aluminium concentration (Table 1), which was from 46- to 72-fold higher when soil was added, while silicon increased by only 0.40 to 0.45 times. Thus, in the context of this experiment the aluminium content is an important indicator of soil contamination in forages.

\section{Ensiling soil contaminated forage}

The Fe content in grass silages was strongly influenced by the degree of soil contamination and soil origin. The higher concentration of trace elements at lower DM content can be probably explained by the better adherence of soil to wetter forage. Soil contamination slightly decreased nutrient concentration of main nutrients such as crude protein. However, major mineral elements were not affected; therefore the DCAD was not changed by the treatments. In the Trial 2, ensiling increased the solubility of Fe from 7 to $34 \%$ on average for fresh and ensiled grass, respectively. This is not as high as observed with whole crop maize (Hansen and Spears, 2009). Nevertheless, a clear increase in bioaccessibility of Fe can be assumed. Ensiling did not change the concentration of minerals unlike often observed in practice. That might be due to a low loss of organic matter in small experimental silos. Soil contamination is seen as one factor to provoke clostridial fermentation (Pahlow et al., 2003). However, in our case, fermentation quality was not altered negatively. In the Trial 2 , the added 
$\mathrm{NaNO}_{2}$ might have helped to counteract clostridial activity (Kaiser and Weiss, 2007). However, in Trial 1 no additive was applied. Optimal ensiling conditions at laboratory scale might have triggered the lactic acid fermentation with a rapid $\mathrm{pH}$ decline thus suppressing butyric acid bacteria.

\section{Feeding of soil contaminated silage}

The higher Fe content in Soil ${ }_{\text {post }}$ treatment in comparison to Soil pre treatment might be explained by field losses of soil during baling and its higher moisture content at ensiling. Despite a nearly 4- to 6-fold higher Fe intake by Soil ${ }_{\text {pre }}$ and Soilpost groups, the Fe content in the liver of the goats was only doubled as compared to the control. This corresponds to findings of Enculescu et al. (2017) who stated that $\mathrm{Fe}$ pools do not respond to dietary changes in a proportional manner. The uptake of Fe from the intestinal lumen into duodenal enterocytes via the divalent metal Fe transporter 1 (DMT1) is regulated locally by cellular Fe levels and increased by the presence of reducing substances such as different proteins in the arterial blood (Kirchgessner et al., 2008; Hansen et al., 2010). In conditions of excess Fe supply, Fe transporters are downregulated by $\mathrm{Fe}$ regulatory proteins/Fe responsive elements to decrease Fe absorption (Galy et al., 2013). Thus, it seems to be reasonable that the highest relative increase in $\mathrm{Fe}$ concentration was found in the duodenal tissue of Soil ${ }_{\text {pre }}$ group, followed by the liver. This observation confirms, at the same time, that more absorbable $\mathrm{Fe}$ was present than in Soil ${ }_{\text {post }}$ treatment as described by Whitehead (2000) and Hansen and Spears (2009) and as shown by the increased Fe solubility in the ensiling trial. The enhanced Fe content in the intestinal tissue of Soil $1_{\text {pre }}$ group in our study is in contrast to a study on calves by Hansen et al. (2010), in which $\mathrm{Fe}$ content remained stable when $\mathrm{Fe}$ was supplemented as $\mathrm{FeSO}_{4}$, but damage of intestinal epithelium was observed suggesting increased permeability of the calves' duodenum to foreign pathogens and unregulated absorption of minerals together with other dietary components. However, their finding corresponds to ours on Soil group. That hints to the significance of the kind of Fe compound reaching the duodenum. Antagonistic interactions between $\mathrm{Fe}$, zinc, copper and manganese because of their competition for DMT1 as described by e.g., Davidson et al. (2015) and Suttle (2010) were not observed in the analysed organs, which is in contrast to findings in sheep (Grün et al., 1978) and goats (Schonewille et al., 1995). On the contrary, zinc and manganese contents were significantly increased in the ham of Soil group. In our study, the possible antagonism was probably compensated by a simultaneously higher supply of zinc and manganese through the added soil. The significantly lower DM concentration of the intestinal tissue in Soil ${ }_{\text {pre }}$ group is an interesting observation. Ponka et al. (2015) described irritation and tissue damage of the gastrointestinal tract as first step of Fe poisoning. It is not clear whether the difference in DM contents is indicative of tissue damage, nevertheless other indications of gastrointestinal damage could be the LWG in Soilpre group, which amounted almost half of the other two experimental groups, and low feed conversion ratio in this group. In Soil ${ }_{\text {pre }}$ group LWG was also depressed by relatively low feed intake which was however statistically similar to the control. Due to the lack of analytical methods, it was not possible to perform a speciation of the inorganic or organic forms in the digesta. This would be of high interest for future studies, as ensiling might increase organically bound fractions, which might have higher solubility. This could be relevant for the biological effects of and for the potential antagonistic impact on other trace minerals. It can be speculated that the observed lower feed intake might also be a consequence of a disturbed intermediary metabolism and other trace elements.

\section{Conclusions}

In the ensiling trials it was shown that soil contamination simulating conditions in agricultural practice can easily lead to high Fe concentrations in resulting silages. In ensiled material, $\mathrm{Fe}$ is present in a more reactive form leading to an increased $\mathrm{Fe}$ solubility and higher concentration in the intestinal tissue of goats. Under Fe abundance, goats are able to regulate $\mathrm{Fe}$ absorption; however, Fe levels in storage organs also were significantly increased. The rise is not proportional to intake, nevertheless enhanced when $\mathrm{Fe}$ is offered in ensiled forage. Although no antagonisms with other trace elements were observed, live weight gain was reduced after feeding soil, which was ensiled with the forage. Ensiling caused increased solubility and thus absorption of Fe. It remains to be investigated how intestinal tissue can tolerate longer periods of overload of ferrous iron, and if so, challenged by pathogenic microorganisms under these conditions. 


\section{References}

Commission of the European Communities, 2009. Commission Regulation (EC) No 152/2009 of 27 January 2009 laying down the methods of sampling and analysis for the official control of feed. Off. J. EU L 54/1, https://eur-lex.europa.eu/legal-content/EN/ALL/?uri=CELEX\%3A32009R0152

Davidson T., Ke Q., Costa M., 2015. Selected molecular mechanisms of metal toxicity and carcinogenicity. In: G.F. Nordberg, B.A. Fowler, M. Nordberg (Editors). Handbook on the Toxicology of Metals (Fourth Edition). Academic Press (an imprint of Elsevier). Cambridge, MA (USA), pp. 173-196, https://doi. org/10.1016/B978-0-444-59453-2.00009-3

DLG (Deutsche Landwirtschafts-Gesellschaft), 2004. Evaluation of Roughage. Part A: Key for the evaluation of fresh forage, silage and hay by sensory evaluation (in German). DLG-Verlag $\mathrm{GmbH}$, Frankfurt am Main (Germany)

DLG (Deutsche Landwirtschafts-Gesellschaft), 2006. Evaluation of Roughage. Part B: Key for the evaluation of fermentation quality of forage silages based on chemical analysis (in German). DLG-Verlag GmbH, Frankfurt am Main (Germany)

EFSA Panel on Additives and Products or Substances used in Animal Feed (FEEDAP), 2016. Safety and efficacy of iron compounds (E1) as feed additives for all animal species: ferrous carbonate; ferric chloride, hexahydrate; ferrous fumarate; ferrous sulphate, heptahydrate; ferrous sulphate, monohydrate; ferrous chelate of amino acids, hydrate; ferrous chelate of glycine, hydrate, based on a dossier submitted by FEFANA asbl. EFSA J. 14, 4396, https://doi.org/10.2903/j.efsa.2016.4396

Enculescu M., Metzendorf C., Sparla R., Hahnel M., Bode J., Muckenthaler M.U., Legewie S., 2017. Modelling systemic iron regulation during dietary iron overload and acute inflammation: role of hepcidin-independent mechanisms. PLoS Comput. Biol. 13, e1005322, https://doi.org/10.1371/journal.pcbi.1005322

Ender F., Dishington I.W., Helgebostad A., 1971. Calcium balance studies in dairy cows under experimental induction and prevention of hypocalcaemic paresis puerperalis. Z. Tierphysiol. Tierernähr. Futtermittelkd. 28, 233-256, https://doi. org/10.1111/j.1439-0396.1971.tb01573.x

European Union, 2003. Commission Regulation (EC) No 1334/2003 of 25 July 2003 amending the conditions for authorisation of a number of additives in feedingstuffs belonging to the group of trace elements. Off. J. L 187, 11-15

Flachowsky G., Hennig A., Löhnert H.-J., Grün M., 1976. Excessive oral administration of iron to sheep. 1. Digestibility of rations, results of fattening and carcass yields (in German). Arch. Anim. Nutr. 26, 765-771, https://doi.org/10.1080/17450397609423276

Galy B., Ferring-Appel D., Becker C., Gretz N., Gröne H.-J., Schümann K., Hentze M.W., 2013. Iron regulatory proteins control a mucosal block to intestinal iron absorption. Cell Rep. 3 , 844-857, https://doi.org/10.1016/j.celrep.2013.02.026

Ganz T., 2003. Hepcidin, a key regulator of iron metabolism and mediator of anemia of inflammation. Blood 102, 783-788, https:// doi.org/10.1182/blood-2003-03-0672

GfE, 1995. Energy evaluation for ruminants (in German). Proc. Soc. Nutr. Physiol. 4, 121-123

GfE, 2001. Recommendations for the Supply of Energy and Nutrients to Dairy Cows and Growing Cattle (in German). DLG-Verlag $\mathrm{GmbH}$, Frankfurt am Main (Germany)

GfE, 2003. Recommendations for the Supply of Energy and Nutrients to Goats. DLG-Verlag GmbH, Frankfurt am Main (Germany)
Grün M., Anke M., Hennig A., Seffner W., Partschefeld M., Flachowsky G., Groppel B., 1978. Excessive iron administration to sheep. 2. The effect on the iron, copper, zinc and manganese level in different organs (in German). Arch. Anim. Nutr. 28, 341-347, https://doi.org/10.1080/17450397809426811

Hansen S.L., Ashwell M.S., Moeser A.J., Fry R.S., Knutson M.D., Spears J.W., 2010. High dietary iron reduces transporters involved in iron and manganese metabolism and increases intestinal permeability in calves. J. Dairy Sci. 93, 656-665, https://doi.org/10.3168/jds.2009-2341

Hansen S.L., Spears J.W., 2009. Bioaccessibility of iron from soil is increased by silage fermentation. J. Dairy Sci. 92, 2896-2905, https://doi.org/10.3168/jds.2008-1933

Healy W.B., 1972. In vitro studies on the effects of soil on elements in ruminal, "duodenal", and ileal liquors from sheep. N. Z. J. Agric. Res. 15, 289-305, https://doi.org/10.1080/00288233.197 2.10421257

Honig H., 1990. Evaluation of aerobic stability. In: S. Lindgren, K. Lunden Petterson (Editors). Proceedings of the EUROBAC Conference, Uppsala, 1986 Grovfoder. Grass Forage Rep. 3, 76-82

Kaiser E., Weiss K., 2007. Nitrate content in green forage - importance for fermentation quality and ensiling technological measures (in German). Übers. Tierernährg. 35, 13-30

Kirchgessner M., Roth F.X., Schwarz F.J., Stangl G.I., 2008. Animal Nutrition (in German). DLG-Verlag GmbH, Frankfurt am Main (Germany)

Lamand M., Lab C., Lafarge C., Montel G., 1979. Influence of silage contamination by soil upon trace elements availability in sheep. Ann. Rech. Vet. 10, 571-573

NRC (National Research Council), 2001. Nutrient Requirements of Dairy Cattle. $7^{\text {th }}$ Revised Edition. The National Academies Press. Washington, DC (USA), https://doi.org/10.17226/9825

Pahlow G., Muck R.E., Driehuis F., Oude Elferink S.J.W.H., Spoelstra S.F., 2003. Microbiology of ensiling. In: D.R. Buxton, R.E. Muck, J.H. Harrison (Editors). Silage Science and Technology. American Society of Agronomy, Inc., Crop Science Society of America, Inc., Soil Science Society of America, Inc. Madison, WI, (USA), pp. 31-93

Ponka P., Tenenbein M., Eaton J.W., 2015. Iron. In: G.F. Nordberg, B.A. Fowler, M. Nordberg (Editors). Handbook on the Toxicology of Metals (Fourth Edition). Academic Press (an imprint of Elsevier). Cambridge, MA (USA), pp. 879-902, https://doi. org/10.1016/B978-0-444-59453-2.00041-X

Schonewille J.Th., Yu S., Beynen A.C., 1995. High iron intake depresses hepatic copper content in goats. Vet. Quart. 17, 14-17, https://doi.org/10.1080/01652176.1995.9694523

Standish J.F., Ammerman C.B., Simpson C.F., Neal F.C., Palmer A.Z., 1969. Influence of graded levels of dietary iron, as ferrous sulfate, on performance and tissue mineral composition of steers. J. Anim. Sci. 29, 496-503, https://doi.org/10.2527/ jas1969.293496x

Steinhöfel O., Willnat J., Giehler J., Zeyner A., 2016. Differences in sulphur and iron content of feeds from saxon dairy farms in the past 15 years depending on location and feed type (in German). In: S. Martens, I. Heber, G. Riehl, O. Steinhöfel (Editors). More Milk from Saxon Grass and Native Protein Feeds (in German). Saxon State Office for Environment, Agriculture and Geology (LfULG). Dresden (Germany), pp. 122-126, https://publikationen.sachsen.de/bdb/artikel/13684

Suttle N., 2010. Mineral Nutrition of Livestock. $4^{\text {th }}$ Edition. CABI. Wallingford (UK), https://doi.org/10.1079/9781845934729.0000 
VDLUFA, 1976. VDLUFA Book of Methods Volume III. The Chemical

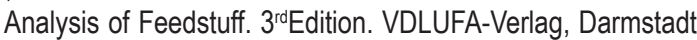
(Germany)

VDLUFA, 1997. Determination of $\mathrm{HCl}$ insoluble ash. In: Association of German Agricultural Analytic and Research Institutes (VDLUFA). VDLUFA Book of Methods Volume III. The Chemical Analysis of Feedstuff. $4^{\text {th }}$ Supplement. VDLUFAVerlag. Darmstadt (Germany)
Whitehead D.C., 2000. Micronutrient cations: iron, manganese, zinc, copper and cobalt. In: D.C. Whitehead (Editor). Nutrient Elements in Grassland: Soil-Plant-Animal Relationships. CABI. Wallingford, (UK), pp. 220-254, https://doi. org/10.1079/9780851994376.0220 